\title{
Identity Politics in Managing the System Risks of Nation- Building: On the Example of the Republic of Kazakhstan
}

\author{
Vladimir Dunaev \\ Valentina Kurganskaya \\ Mukhtarbek Shaikemelev \\ Institute for Philosophy, Political Sciences \\ and Religion Studies \\ Kurmangazy str. 29, \\ Almaty 050010, \\ The Republic of Kazakhstan \\ E-mail: iph@iph.kz
}

Abstract: In previous years, the evolution of nation-building politics in the Republic of Kazakhstan was characterized by an alternation of tactical schemes that actualized either the ethnocultural or civil-political foundations of statehood. At present, the emerging common Kazakhstani culture is becoming the basis for mutually agreed development of ethnocultural and civic identity as its own elements. In the system of common Kazakhstani culture, the civil and ethnocultural models of the nation are the poles or attractors of the process of self-organization of a single nationwide Kazakhstan identity. The optimal identity politics in the nation-building risk management in the conditions of modern Kazakhstan is to adopt the point of view of the whole set of identification models and to maintain the dynamic balance of conflicting identities through the mechanism of mutual checks and balances.

Keywords: civil nationalism, cosmopolitanism, ethnonationalism, identity politics, multiculturalism, nation, national state, nation-building 


\section{Introduction}

After the publication of Samuel Huntington's bestseller The Clash of Civilizations (1993), the idea that the modern multipolar world order is shaped by various types of cultural and civilizational identification, defining models of cohesion, disintegration and conflict, has become generally accepted. The axis of the emergence of a new world order is the "fundamental question of identity" (Huntington, 1998, p. 125). At the same time, the remaking of the architecture of the world order is accompanied by the crises of national identity, the reassessment of traditional ethnocultural values, the rejection of the former and the testing of new models of nation-building and the formation of national identity.

As stated in the UN report Cultural Freedom in the Modern World, building a national state with a unitary cultural identity based on the sense of common history, values and beliefs shared by the people of the country was the dominant trend of national development and "the main political project of the 20th century" (UNDP, 2004, p. 55). This project goes back to the Westphalian model of coexistence of sovereign nation-states as the main structure of a sustainable world order. The new millennium is characterized by the advancement of a new political project, according to which both the individual state and the world as a whole should build their unity on the basis of the political and legal realization of the legitimacy of multiple and complementary identities. "Contextually labile identification", the formation of "ambiguous, ambivalent, hybrid, transversal and multi-layered" (Golob, 2014, p. 124) identities, are becoming the standard of social identification processes in the rapidly changing world of the 21 st century.

Under the influence of globalization, cultural-civilizational and national-state identities "had to give way to subnational, group and religious identities" (Huntington, 2004, p. 36), woven into transnational networks of communicative interactions. Modernity "deconstructs" transnational, national-state and nationalcultural identity based on the principles of cosmopolitanism and neotribalism. A completely different logic of nation-building and a new set of requirements for concepts, strategies and political technologies for the formation of national identity should be formed in accordance with the cumulative action of these multidirectional trends.

As noted by the Russian experts V. I. Pantin and V. V. Lapkin, the authorities of the Republic of Kazakhstan "managed to work out a compromise and highly non-trivial identity politics, which allowed for the consolidation of the republic on new grounds" (Pantin \& Lapkin, 2015, p. 84). Drawing on the Kazakhstani 
experience of nation-building and pursuing an identity politics is of an obvious interest, since almost all nations in the modern world are faced with the need to develop new self-description languages, new institutional forms and selfidentification strategies.

This article is intended to identify and analyze the characteristic features of the identity policy, permitting the Kazakhstani state to manage systemic risks of nation-building in a multi-ethnic society to a large extent. This goal is achieved on the basis of a solution to a range of the following tasks:

- To reveal the political and ideological implications of the main normativetheoretical models of the national identity;

- To justify the inconsistency of confrontational models of the relationship between national-cultural and civil-political identities;

- To trace the evolution of Kazakhstani national-state building policy: from tactical maneuvering between ethnocultural and civil-political components of the national identity till transition to an integrated model of political identity management;

- To reveal and analyze the conceptual foundations of the policy of common Kazakhstani identity formation.

\section{Normative-theoretical models and ideological attitudes of identity politics}

There are two main ideal types of understanding of a nation that circulate in the modern political discourse. Understanding the nation as a political community (Staatsnation) or co-citizenship, irrespective of ethnic, linguistic, religious differences, traces its genealogy to J.-J. Rousseau and is characteristic of Western European political culture. Understanding the nation as a pre-political collective identity (Volksnation), arising in a natural-historical way based on the unity of origin, culture, language, customs, traditions, national spirit (Volksgeist), etc. and existing regardless of the political opinions and will of the citizens themselves, goes back to J. G. Herder and characterizes the uniqueness of Central European and Eastern European political culture. The Germans viewed the nation as a foundation for creation of a state, the French saw the nation as a product of the state. By the German romanticism of the 19th century, the metaphysical validity of the German national spirit as the basis of national statehood was opposed to artificiality, flat rationalism and cosmopolitanism of the French model. In the Anglo-Saxon liberal tradition, "the state nation is designated as rational, 
universal and progressive, and a cultural nation as irrational, particularistic and conservative" (Altermatt, 2000, p. 41).

Kazakhstan's political discourse also presents both alternative models and directly opposite assessments of identity politics as the conceptual basis of a nation-building strategy. The first strategy is aimed at the formation of a unified Kazakhstan nation from a multi-ethnic society based on a common citizenship. The civil community is understood not just as a legal recording of the fact of citizenship, but a high level of civil self-identity of representatives of different ethnic groups. This approach was called "civil nationalism".

The point of view of civil nationalism on the nation building strategy is consistently pursued by Jürgen Habermas. Civil nationalism proceeds from the postulate of political neutrality or political irrelevance of cultural, ethnic, confessional, linguistic, and other identities. Citizenship as a new level of legally mediated solidarity of citizens who overcame the framework of corporate communities and traditional collectivities, also introduces a new type of legitimation of political power, in contrast to dynastic and religious forms of legitimacy. However, the reverse side of the legitimacy of the national state is its duality, the intensity of relations between the particular character of a nation as a cultural community and the universal nature of the legal community. "This tension can be relieved, provided that among the constitutional principles of democracy and human rights, priority will belong to the cosmopolitan understanding of the nation as a nation of citizens, and not the ethnocentric interpretation of the nation as a prepolitical unity" (Habermas, 2002, p. 371).

At first, cultural identity provided a cohesive social basis for political identity of citizens of a nation-state. However, today we all live in multi-ethnic societies characterized by a variety of cultural life forms, religions, and worldviews. From the point of view of Habermas, a culture that claims recognition from all citizens of a state can only be universal political (civic) culture, crystallized around the current constitution and is independent of all forms of non-political identities. Post-national constitutional patriotism, which replaces traditional nationalism, becomes such culture.

Today a national state is confronted with challenges posed by the explosive forces of multiculturalism in its internal affairs, and with the challenges of globalization in the external affairs. Therefore, according to Habermas (2002, pp. 378, 379), the republican heritage can be saved only by going beyond the limits of the national state, bringing "their capabilities for political action in line with the globalization of self-regulating systems and networks". 
The formation of "post-national" political identity of civil society threatens the very existence of a national state in a process designated by Habermas as "denationalization", and Ulrich Beck and Daniel Levy (2013) as "cosmopolitanization" of a national state. Although in the postmodernistically deconstructed world of national identifications, the oxymoron "cosmopolitan nationalism" can turn into an effective form of political practice of nationbuilding. For example, since the 1990s, the cultural policy of Singapore aims to implement cosmopolitanism in the composition of the worldview and the "national spirit" ("cosmopolitan Singapore"), while at the same time enhancing the sense of civic patriotism and collective identity (Chang, 2012).

The postulate on mutual indifference of civic-political identity and pre-political collective identities, coherently pursued by Habermas, prepares a conceptual platform for discreditation of the nation-state. It becomes unviable and dysfunctional in the modern era, when the sovereignty of national states ceases to be the structural basis of the global world order system.

Thus, the immanent logic of nation building on the principles of civic nationalism and the identity politics relevant to this logic lead to an increase in the internal and external risks of dismantling the nation-state. An overarching priority of nation-building in the Republic of Kazakhstan, as repeatedly stated by President Nursultan A. Nazarbayev, is to strengthen national state sovereignty. Thus, consistent implementation of the liberal-cosmopolitan policy of national identity will entail an unacceptable risk in the system of political values of modern Kazakhstan - the loss of state sovereignty.

Habermas is confused by the issue of whether the generalized political culture of a civic nation (and constitutional patriotism as its expression) is a string that is too thin to hold complex, multi-part societies together. If a civic nation is united only by "an intersubjectively shared context of possible mutual understanding" (Habermas, 1999, p. 159), it means that nothing really unites it, or unites it on a negative basis. Since communicative rationality as the only legitimate source of civic identity is basically the ideological euphemism of Kant's concept of civil society as "a system of unfriendly sociability". Elimination of national-cultural identity from a legitimate political process leads to the fact that civil identity based on political participation mutates to its transformed, extreme forms: passive conformist citizenship ("passport identity") and cosmopolitanism.

A number of Kazakhstani experts have come to the conclusion that it is necessary "to use both concepts of the nation-civil and ethnocultural, and not rely only on one of them, while rejecting the second one" (The National 
Idea ..., 2006, p. 11). However, this methodological attitude risks to turn into an eclectic mixture and terminological confusion in the pursuit of identity politics. For example, the Law of the Republic of Kazakhstan "On the Assembly of the People of Kazakhstan" defines the purpose of the Assembly to ensure interethnic harmony on the basis of "the civil, spiritual and cultural community of the people of Kazakhstan with the consolidating role of the Kazakh people" (Zakon Respubliki ..., 2011, p. 122). As can be seen, two meanings of the term "people" are used here in the same sentence: the political and legal concept of people as a synonym for a civic nation and the concept of people as a national-cultural or ethnocultural community.

Another way to overcome the conflicting interpretations of identity is to recognize the presence of elements of both civil and ethnic communities in a nation. A nation is not only a political and legal community of citizens, but also a moral, cultural and value community of compatriots.

The inconsistency of confrontational models of the correlation of nationalcultural and civil-political identity is also recognized by modern political theory. Rogers Brubaker (2004, p. 136) notes: "The civic-ethnic distinction remains both analytically and normatively problematic". In any case, this difference cannot be thought as mutually exclusive. Yuri D. Granin writes:

in modern studies that draw attention to the fact that belonging to a nation is determined by a person in self-identification procedures, 'nation' is understood not as a 'group', but as a 'social community', that is, connected through imagination and united by common feelings of identity and solidarity, common values of the past and the present sociocultural community of people politically united in one state (Granin, 2015, p. 15)

Criticizing the concept of "constitutional patriotism" by Habermas, Aleksandr Posadsky (2015) rightly points out that in reality a civic nation "is both a legal and a spiritual and moral unity. It is built along cultural lines, not across them". The ideological and methodological attitude to use the integrated model of national identity is reflected in the Declaration of the 25th Anniversary of Independence of the Republic of Kazakhstan adopted by the Kazakhstan's Parliament:

The historical synthesis at the intersection of world religions, languages, cultures and traditions has formed a unique type of society in Kazakhstan, in which peace and conciliation became a moral and ethical norm of society, an integral part of our common culture. This made the fusion of spirituality and citizenship especially 
strong, turning polyethnicity and multi-religiosity into a strategic resource and advantage of Kazakhstan. (Deklaratsiia..., 2016)

Supporters of ethnic nationalism, which is an alternative to civic nationalism as a strategy of nation-building, proceed from the fact that building a civil nation in Kazakhstan is impossible. They believe that an individual's ethnic identity will always prevail over his identity with members of other ethnic groups, and therefore over his civic identity. The ideological attitudes of the "nationalpatriotic" opposition to the process of nationalization in Kazakhstan are reflected in the statement of Amangeldy Aitaly (2010): "if we speak in scientific language, we have only one nation. This is the state-forming Kazakh nation".

Ethnonationalism, according to a number of theorists, is a logical consequence of the social transformations of the postmodern era. Slavoj Zhizhek (2005, p. 103) writes: "today we are dealing with a process contrary to what was at the basis of the formation of the modern nation: instead of 'nationalizing ethnic' (deethnicization, 'withdrawing (Aufhebung)' ethnic in national), we now deal with 'ethnicizing national', with a new search (or reconstruction) of 'ethnic roots"'. Andrew Heywood argues that today there is reason to believe that the era of nations is coming to an end. The rise of nationalism was a way to ensure cultural unity in the conditions of industrialization, but in the context of globalization "nations are no longer able to provide a meaningful collective identity or sense of social belonging" (Heywood, 2002, pp. 123, 148).

The main risks of political actualization of the ethnocentrist dominant of identification processes are the transformation of national state into ethnocratic statehood in its unitary or segmental forms. A national state in which ethnic groups are not united by a supra-ethnic identity into a political nation is deprived of immunity from the threats of disintegration. The generalization of valuesemantic schemes of ethnic identification as a model of state-political system becomes a form of politicization of ethnicity itself, i.e. turning democracy into ethnocracy. In modern political science, ethnocracy means a political regime in which "the dominant ethnonation is the owner of absolute sovereignty and the source of supreme power in the state" (Farukshin, 2015, p. 47). However, in the strict sense of the word 'ethnocracy' there is an endowment of ethnic groups with the status of collective political and legal subjects, and not the monopolization of political power by an ethnic majority. Viktor Martyanov (2006, p. 97) writes: "Ethnos within a nation-state cannot be a collective political-legal entity, but only a cultural-historical one". Therefore, multiculturalism as a matrix of national construction through the repolitization of ethnicity, contrary to the doctrinal provisions of liberal ideology, is one of the forms of ethnocracy. The failure 
of the European multiculturalism policy officially recognized by the leaders of major European nations is connected with this circumstance.

In fact, the strategic goal of the renewed European multiculturalism policy is its turning towards the goals of achieving social harmony, nation-wide consolidation - that is, the very goals pursued by Kazakhstan's national politics throughout its development as a sovereign state. The logical-methodological matrix of the politics of achieving national unity, "based on recognition of a common system of values and principles for all citizens" (Doktrina..., 2010) is not a "disjunctive synthesis" of Deleuze's differences, but the unity of diversity. The Doctrine of the National Unity of Kazakhstan states: "Our main wealth is unity in diversity" (Doktrina..., 2010). In other words, true multiculturalism can be achieved only on the basis and in the context of national unity.

In the contemporary discourse of multiculturalism, the policy of promoting ethnocultural diversity is viewed as a challenge to national-state unity. In Kazakhstan, the state policy of supporting ethnocultural diversity is aimed at strengthening the civil-political, cultural, and spiritual unity of the people as the only source of sovereignty of the national state.

The post-modernist situation is defined as such a historical moment when the very form of the nation-state is actively and purposefully driven out of the historical scene. A prominent role in this process aimed at discrediting the legitimizing functions of the nation-state belongs to a number of neoliberal ideologists of multiculturalism. They believe that transnational and extraterritorial structures ultimately not only devalue the status of the state as a subject of world order, but also crush national-state sovereignty. For example, the authors of the UN Report Cultural Freedom in the Modern Diverse World write: "Unfortunately, in today's debate on globalization and loss of cultural identity, arguments are often expressed in terms of defending the national sovereignty." Meanwhile, according to the writers of the Report, the new architecture of the world assumes that "multiple and complementary identities emerging in globalization processes will go beyond state borders" (UNDP, 2004, p. 107). Regarding this kind of reasoning, Zygmunt Bauman (2001, p. 193) ironically remarks: "Weak states are precisely what the New World Order, all too often looking suspiciously like a new world disorder, needs to sustain and reproduce itself". The policy of leaving the nation out of the game in international politics is laid largely through the conceptual redefinition of the foundations of national identity. Postmodernism deprives political ideologies of legitimacy that rely on the national state and, accordingly, on civil and ethnocultural nationalism. At the same time, the postmodern ideology is forced to legitimize marginal 
or artificially constructed types of communities (nomadic race-tribes), deviant social practices, and arbitrary "assemblies" of conceptually conflicting identities confronting a nation-state.

Thus, a one-sided reliance on each of the models of nation-building generates, on various bases, in various forms and with varying degrees of intensity, an increase in the strategic risks of identity politics - the disintegration of civilian community and the dismantling of the nation-state.

\section{Nation-building strategy and the principle of interchange of tactical identity politics schemes}

In the first years after the proclamation of state independence, the elements of ethnonationalism inevitable for that time provided the foundation for the Kazakhstani ideology of nation-building. The Constitutional Law dated December 16, 1991, On the National Independence of the Republic of Kazakhstan contained the provision on "the right of the Kazakh nation for self-identification" (Konstitutsionnyi zakon..., 1991). In the First Constitution of the Republic of Kazakhstan (adopted on January 28, 1993), the Republic of Kazakhstan was defined as "a form of statehood of a self-defined Kazakh nation", while the Kazakhs were assigned the status of both the "ethnocultural core of Kazakhstani statehood" and the "state-forming nation" (Konstitutsiia Respubliki Kazakhstan, 1993). Thus, the ethnic self-identification of the titular nation was adopted as the basis and normative model of civil-political and ethnonational identity. Meanwhile, the concept of 'state-forming nation' deprives the concept of common Kazakhstani national-state identity of the meaning. It makes it structurally impossible to form a civic nation and generates a political segmentation of society along the lines of ethnic identification processes.

The change in the course of identity politics was marked by constitutional consolidation of the provision on the people of Kazakhstan as a political community of citizens of different ethnic groups, that is, as a civic nation. From the Constitution of 1995, the provision on the "state-forming nation" was deleted. 'On the Concept of Forming the State Identity of the Republic of Kazakhstan' (1996) mentions the following principle, which is the most important for the liberal doctrine of nation building and identity politics:

The definition of Kazakhstan as a national state takes into account the strategic trend in the development of state identity - the formation of 
a nation-state in the future. Such a state, which citizens, irrespective of ethnicity, form a single people, and the belonging to which is the main identifying feature for them. ('O kontseptsii ...', 1996)

The analysis of official documents (program articles and speeches of the President of the country; documents of the Assembly of the People of Kazakhstan; national politics concepts and programs adopted by the Government of the Republic of Kazakhstan, development of secondary and higher education, cultural and language politics, etc.) allows us to conclude that later on the evolution of the national-state building politics was characterized by the alternation of tactical schemes that actualize ethnocultural or civil-political foundations of statehood. From 2012-2013, after the promulgation of the Kazakhstan 2050 Strategy, the national policy began to build on the principle of organic unity of civil and national-cultural identity.

How can this type of identity political management model be explained and interpreted? The fact is that in the modern world, national identity is not a fixed state or quality, but the process of its formation. "Cultural identities are created in a constant dialogue, negotiation, and contest of similarity and difference, sameness and distinction. The constructed and multilayered nature of cultural identity is a fundamental point of departure in understanding such phenomena. Cultural identities can be understood as processes taking various forms with respect to a particular time, place, and discourse" (Lähdesmäki, 2014, p. 72). V. A. Tishkov (2003, p. 123) describes ethnic identity as "a journey of individual/collective identity across a set of currently available cultural configurations or systems, and in some cases these systems arise as a result of identity drift'. Identity management is to contain the identity drift in the area with the least concentration of threats and risks to the sustainable development of the nation-state.

The abrupt change of identity politics vectors, such as when adopting the second edition of the Constitution of the Republic of Kazakhstan, accompanied the adoption of decisions, most important for the national construction, in the field of language, education, migration, and personnel politics of the state. This harshness was explained by the fact that Kazakhstan was in the phase of a radical reform of the most important spheres of the social whole: the economy, politics, culture, ideology. In his Address to the People of Kazakhstan on Kazakhstan 2050 Strategy, Nazarbayev (2012) stated that Kazakhstan had entered a new phase of development - it had achieved the status of an established state. From this point on, the evolutionary path of development became a priority. Accordingly, the amplitude and intensity of fluctuations of the identity politics between its alternative directions were minimized. 
As an illustration of transition to a new political philosophy of national identity formation, we can refer to the difference between the two strategies for modernizing public consciousness, announced in 1997 and 2017. The Kazakhstan 2030 Strategy, adopted in 1997, outlined the program of implementing Kazakhstan's postulates of the neoliberal market fundamentalism in public consciousness - the psychology of private-ownership individualism and the cosmopolitan model of the formation of civic identity:

The rapid development of private-ownership individualism not only contributed to the change of value orientation, but also undermined the deep roots of interethnic contradictions... Our movement towards a market that is cosmopolitan and international, does a great job-it weakens interethnic contradictions. (Nazarbayev, 1997)

This strategic program was motivated by the need to adapt the cultural-historical tradition "to a qualitatively different system of values and a new type of human relationship." Strategy 2030 required a radical restructuring of the public consciousness, suggesting a crisis-catastrophic scenario of transforming the traditional mentality: "Replacing a state-collective worldview with a privateownership one changed every aspect of our life" (Nazarbayev, 1997).

In April 2017, the President of Kazakhstan published a program article 'The course towards the future: modernization of public consciousness' (Nazarbayev, 2017). A fundamentally different model of national identity formation was proposed here: "The first condition for modernizing a new type is to preserve one's culture, one's own national code", "preserve the inner core of the national 'I' while changing some of its features" that hinder the development of a nation. As you can see, this is no longer a question of replacing, but of updating the ideological attitudes of national identity. It is not the market cosmopolitanism with its arrogant attitude to historical experience and national identity, but the spiritual roots of tradition that should be the basis of nation-building: "A special attitude to native land, its culture, customs, traditions is... the foundation of the cultural-genetic code that makes any nation a nation, not a collection of individuals" (Nazarbayev, 2017).

The fundamentally important provision in the framework of the problems of this article is that the modernization of public consciousness should occur within preservation of national identity. The achievement of coherence of trajectories, rhythms, and poles of attraction of national identity should become the matrix of spiritual modernization process - "the most important mission of spiritual modernization is to reconcile the different poles of national consciousness" (Nazarbayev, 2017). 
Acquiring the status of an established state implies "inversion of the method" in the conceptualization of the nation-building and identity politics model. Considering the historical background of the capitalist economy and its relationship to capital, "which, based on its own reality, sets the conditions of its own realization itself," Marx (1980, p. 453) shows that at the final stage of its transformation into the system of social production, the capital transforms the historical background and conditions of its formation into the result of its own being. As applied to the nation-construction models, this inversion of the method means that the formed common Kazakhstani culture becomes the basis for reformatting the ethnocultural and civic identity in accordance with the new systemic quality they acquired. As a qualitatively defined whole, a single Kazakhstani culture includes, for example, Kazakh-Russian bilingualism, common holidays, values, symbols, spiritual authorities, common features of mentality, social and psychological characteristics, etc. Of course, in the common Kazakhstani culture, in fact, the values, symbols and language of the Kazakhs prevail and will steadily expand. But the whole thing is, as a matter of principle, in the matrix of the formation of Kazakhstan's national identity. A national identity is formed on the substrate of ethnic identities, but as a completely different, systemic quality, which has a different meaning, different logic, and different structure. According to the President of Kazakhstan, in the self-reproduction of the common Kazakhstani culture, the civil and ethnocultural models of a nation are the poles or attractors of the process of self-organization of a single nationwide Kazakhstan identity. National identity acquires a dual mode of existence: (1) as a relatively independent whole, within which ethnocultural identification proceeds, and (2) as an organic part of a wider whole - a common Kazakhstan identity that is already being formed on its own basis. With such a foundation of national identity, its formation does not need a homogeneous nation as its substrate and in a cosmopolitan civic culture as the political ideology of a multiethnic nation-state.

\section{Conclusions}

According to the completed study, a number of general conclusions can be made:

1. Ideological injections cannot be an effective means of preventing and combating socially destructive changes in the identification structures of social consciousness. The main principle of consistent democratic identity politics is to prevent the risks of radicalization of identification processes. Meanwhile, it 
is necessary to observe the sui generis right of a nation to self-identification as the right of public consciousness for national identity on the basis of the reasons, motives and criteria that are significant in its own value-based hierarchy.

2. There are three dominant ideologemes of nation-building circulating: ethnonationalism, civic nationalism, multiculturalism and their numerous hybridizations in modern political discourse. None of these paradigms provides for the achievement of the true unity of diversity as a logical structure of the national identity. Each is one-sided, focusing either on variety (multiculturalism), or on homogenizing the ethnocultural landscape of the nation (ethnonationalism), or on dispensing principles of unity and diversity to different subjects of inherence (civil nationalism).

3. Integrated multidimensional model, combining positive components of the principles of formation of an ethnocultural and civil nation and multicultural attitudes, meets the challenges of nation-building and formation of national identity in modern Kazakhstan to the fullest extent.

4. Accordingly, the nation-building risk management strategy optimal for the Kazakhstani society at the present stage of its development is to maintain the dynamic balance of conflicting identities through a system of mutual checks and balances and mobilization of compensatory mechanisms, taking the standpoint of the entire set of identification models.

Opportunities for strategic planning and political management of the Kazakh identity formation processes are most fully realized if in the popular consciousness the understanding of a nation will be determined by the concept of a civic nation in the format of a single civil-political, cultural-historical and spiritual-moral community - the Kazakh people. This model of nation-building in no way denies the "factor of ethnicity" and its significance in the life of society and individuals, opening up a wide range of possibilities for ethnic selfdefinition.

Vladimir Yurievich Dunaev is a doctor of philosophical sciences, professor, and chief researcher of the Department of Political Science at the Institute for Philosophy, Political Sciences and Religion Studies (IPPR), Almaty, Republic of Kazakhstan. His major fields of research are ontology and epistemology, social philosophy, political philosophy, and philosophy of culture.

Valentina Dmitrievna Kurganskaya is a doctor of philosophical sciences, professor, and chief researcher of the Department of Political Science at the Institute for Philosophy, 
Political Sciences and Religion Studies (IPPR), Almaty, Republic of Kazakhstan. Her major fields of research are interethnic relations, nation-building, history of philosophy, political philosophy, and philosophy of culture.

Mukhtarbek Seid-Aliyevich Shaikemelev is a doctor of philosophical sciences, head of the Department of Political Science at the Institute for Philosophy, Political Sciences and Religion Studies of the Ministry of Education and Science of RK. Shaikemelev has conducted research in the sphere of national politics, interethnic relationships, political technologies and public administration.

\section{References}

Aitaly, A. (2010), 'We are strong in unity,'Aktiubinskii Vestnik, 29 April. Retrieved from http://avestnik.kz/amangeldy-ajtaly-my-silny-edinstvom-2 [accessed 8 Feb 2019] Altermatt, U. (2000), Etnonatsionalizm v Evrope [Ethnonationalism in Europe], Moscow: Russian State University for the Humanities.

Bauman, Z. (2001), The Individualized Society, Cambridge: Polity Press.

Beck, U. \& Levy, D. (2013), 'Cosmopolitanized nations: re-imagining collectivity in world risk society,' Theory, Culture and Society, vol. 30, no. 2, pp. 3-31. https://doi.org/10.1177/0263276412457223

Brubaker, R. (2004), Ethnicity without Groups, Cambridge, MA: Harvard University Press.

Chang, P.-C. (2012), 'Going global and staying local: nation-building discourses in Singapore's cultural policies,' Identities: Global Studies in Culture and Power, vol. 19, no. 6, pp. 691-707. https://doi.org/10.1080/1070289X.2012.745409.

Deklaratsiia... (2016), Deklaratsiia 25-letiia Nezavisimosti Respubliki Kazakhstan (Polnyi tekst) [Declaration of the 25th anniversary of Independence of the Republic of Kazakhstan (full text)], 23 November. Retrieved from http:/www.matritca.kz/ news/39092-deklaraciya-25-letiya-nezavisimosti-respubliki-kazahstan-polnyytekst.html [accessed 3 Mar 2019]

Doktrina... (2010), Doktrina natsionalnogo edinstva Kazakhstana [The Doctrine of National Unity of Kazakhstan], 29 April. Retrieved from http://online.zakon.kz/m/ document /? Doc_id = 30501158 [accessed 9 Mar 2019]

Farukshin, M. H. (2015), 'Etnokratiia: zarubezhnyi diskurs' [Ethnocracy: foreign discourse], Socis. Sociological Studies, no. 4, pp. 44-59.

Golob, T. (2014), 'Exploring identifications in the transnational social sphere: the potential of social fields,' Sotsiologiia i postor, vol. 52, no. 2(199), pp. 123-139. https://doi.org/10.5673/sip.52.2.1 
Granin, Yu. D. (2015), “"Natsiia” i “etnos": evolutsiia podkhodov i interpretatsii v filosofii i nauke XVIII-XX stoletii' ["Nation" and "ethnos": the evolution of approaches and interpretations in philosophy and science of the XVIII-XX centuries], Voprosy filosofii, no. 7, pp. 5-16.

Habermas, J. (1999), The Inclusion of the Other: Studies in Political Theory, Cambridge: Polity Press.

Habermas, J. (2002), 'Evropeiskoe natsionalnoe gosudarstvo: ego dostizheniia i predely. O proshlom i budushchem suvereniteta i grazhdanstva' ['The European nation state: its achievements and its limitations. On the past and future of sovereignty and citizenship], in B. Anderson et al. (eds.) Natsii i natsionalizm [Nations and Nationalism], transl. from English and German by L. E. Pereyaslavceva, M. S. Panin \& M. B. Gnedovskiy, Moscow: Praksis, pp. 364-380.

Heywood, A. (2002), Politics, London: Springer Nature Limited.

Huntington, S. (1998), The Clash of Civilizations and the Remaking of World Order, New York \& London: Simon \& Schuster.

Huntington, S. (2004), Who Are We? The Challenges to America's National Identity, New York \& London: Simon \& Schuster.

Konstitutsiia Respubliki Kazakhstan (1993), Verkhovnyi Sovet Respubliki Kazakhstan ot 28 ianvaria 1993 goda. [Constitution of the Republic of Kazakhstan, Adopted at the ninth session of the Supreme Council of the Republic of Kazakhstan of the twelfth convocation on January 28, 1993]. Retrieved from https://zakon.uchet.kz/ rus/history/K930001000_06.09.1995 [accessed 12 Feb 2019]

Konstitutsionnyi zakon... (1991), Konstitutsionnyi zakon Respubliki Kazakhstan 'O gosudarstvennoi nezavisimosti Respubliki Kazakhstan' [The Constitutional Law of the Republic of Kazakhstan of December 16, 1991 No. 1007-XII 'On the State Independence of the Republic of Kazakhstan']. Retrieved from http://online. zakon.kz/document/?doc_id=1000798 [accessed 11 Feb 2019]

Lähdesmäki, T. (2014), 'The influence of cultural competence on the interpretations of territorial identities in European Capitals of Culture,' Baltic Journal of European Studies, vol. 4, no. 1(16), pp. 69-96. https://doi.org/10.2478/bjes-2014-0005

Martyanov, V. (2006), 'Stroitelstvo politicheskoi natsii i etnonatsionalizm' [Building a political nation and ethnonationalism], Logos, no. 2(53), pp. 94-109.

Marx, K. (1980), Ekonomicheskie rukopisi 1857-1861 gg.: Pervonachalnyi variant Kapitala [Economic manuscripts of 1857-1861, Initial version of Capital], vol. 1, Moscow: Politizdat.

Nazarbayev, N. A. (1997), 'Kazakhstan-2030. Prosperity, security and ever growing welfare of all Kazakhstanis,' Address by the President of the Republic to the people of Kazakhstan. Retrieved from http://massaget.kz/laws/rus/docs/K970002030 [accessed 11 Feb 2019] 
Nazarbayev, N. A. (2012), 'Strategy 'Kazakhstan-2050'. A new political course held by the state,' Address by the President of the Republic of Kazakhstan-Leader of the Nation N. A. Nazarbayev to the people of Kazakhstan. Retrieved from http:// adilet.zan.kz/rus/docs/K1200002050 [accessed 17 Feb 2019]

Nazarbayev, N.A. (2017), 'Vzgliad v budushchee: modernizatsiia obshchestvennogo soznaniia,' [The course towards the future: modernization of public consciousness]. Retrieved from http://online.zakon.kz/Document/?doc_id=36155529 [accessed 18 Feb 2019]

'O kontseptsii...' (1996), 'O kontseptsii formirovaniia gosudarstvennoi identichnosti Respubliki Kazakhstan' [The concept of the formation of state identity of the Republic of Kazakhstan], Razporiazhenie Prezidenta Respubliki Kazakhstan ot 23 maia 1996 goda N 2995. Retrieved from http://kazakhstan.news-city.info/docs/ sistemsl/dok_pegeez.htm [accessed 11 Feb 2019]

Pantin, V. I. \& Lapkin, V. V. (2015), 'Ethnopolitical and ethnosocial processes in postSoviet countries (Russia, Belarus, Kazakhstan and Ukraine cases),' Polis. Political Studies, no. 4, pp. 75-93. https://doi.org 10.17976/jpps/2016.04.06

Posadsky, A. (2015), 'Zapadnye teorii grazhdanskoi natsii: sushchnostnye kharakteristiki i posledstviia vnedreniia' [Western theories of a civic nation: essential characteristics and implications of implementation], Vsemirnyi Russkii Narodnyi Sobor, 10 July. Retrieved from http://www.vrns.ru/experts/3902 [accessed 15 Feb 2019]

The National Idea... (2006), The National Idea of Kazakhstan: The Experience of Philosophical and Political Analysis, Almaty: Institute for Philosophy and Political Science MES RK.

Tishkov, V. A. (2003), Rekviem po etnosy: Issledovaniia po sotsialno-kulturnoi antropologii [Requiem for ethnos: Studies on socio-cultural anthropology], Moscow: Nauka.

UNDP (2004), Human Development Report 2004. Cultural Freedom in the Modern Diverse World, Oxford: United Nations Development Programme.

Zakon Respubliki... (2011), Zakon Respubliki Kazakhstan ot 20 oktiabria 2008 goda No 70-IV 'Ob Assamblee naroda Kazakhstana' [About the Assembly of the People of Kazakhstan. Law of the Republic of Kazakhstan dated October 20, 2008], in E. L. Tugzhanov (ed.) Gosudarstvennaia etnopolitika Kazakhstana: novye trendy: Metodicheskie posobie [National ethnopolitics of Kazakhstan: new trends: a methodological manual], Astana: Academy of Public Administration under the President of the Republic of Kazakhstan, pp. 122-131.

Zhizhek, S. (2005), 'Multikulturalizm, ili kulturnaia logika mnogonatsionalnogo kapitalizma' [Multiculturalism, or the cultural logic of multinational capitalism], in S. Zhizhek (ed.) Interpassivnost', Zhelanie: Vlechenie. Multikulturalizm [Interpassivity. Desire: Attraction. Multiculturalism], St. Petersburg: Aletejya, pp. 59-147. 